\title{
Current status and future perspectives of immunotherapy in Latin America and Cuba
}

\author{
Alexander Diaz Rodriguez ${ }^{1 *}$, Alexis Labrada Rosado ${ }^{2}$, Raúl Lázaro Castro Almarales ${ }^{2}$ and Mirta Álvarez Castelló ${ }^{3}$
}

\begin{abstract}
Most Latin-American countries use subcutaneous immunotherapy (SCIT) extracts from the United States and Europe and sublingual immunotherapy (SLIT) from Europe, with the exception of Argentina, Brazil, Cuba and Mexico. The number of researches on immunotherapy (IT) in Latin America has increased extensively in the last years. Only few Latin American countries have their own guidelines on IT, and, in general, the economic resources for medical research on IT are still low in the area. A global approach for the future of IT in Latin America includes to improve standardization, quality control and the production of allergen products, to develop IT guidelines and clinical investigation by the highest number of countries, to improve the regulatory status for allergens products in the area, and to expand IT accessibility for low-income patients. In Cuba, the first registered allergen vaccines were developed and registered in 2006: a standardized (in biologic units) and freeze dried product for SCIT, with a sublingual version developed in 2009. As much as 23.000 IT treatments were applied in 2011, all provided to patients free of charge. In 2012, Cuban researchers developed an IT vaccine with adjuvant for subcutaneous route, which uses Neisseria meningitidis proteoliposome as an adjuvant, added to the purified Dermatophagoides siboney major allergens: Der $s 1$ and Der s2. Since December 2012, this vaccine is in Phase I clinical trial, evaluating its safety, tolerability and immunogenicity in asthmatic patients sensitized to this allergen. Cuban perspectives on IT includes to work on new indications for IT, to investigate the preventive effect and cost-effectiveness for the current vaccines, to develop new products with mixed formulas of house dust mites for SLIT, to complete the phase I and II clinical study for dust mite plus adjuvant vaccine, to develop allergen vaccines for fungi allergy and to complete the Cuban guideline for allergen IT management.
\end{abstract}

Keywords: Immunotherapy, Latin America, Cuba

\section{Introduction}

Allergic diseases represent an economic burden for health system, both in direct and indirect costs. Allergen-specific immunotherapy is one of the most important treatments for allergic disorders, so that the development in this area can be considered a sensitive indicator regarding the advances in the management of allergic diseases in a specific area or country. In addition, allergen-specific immunotherapy is currently recognized as a biological response modifier and the only treatment able to influence the natural course of allergic disease [1].

Several randomized, placebo-controlled studies and meta-analysis have confirmed the effectiveness of immunotherapy in asthma and rhinitis, with a significant

\footnotetext{
* Correspondence: diaz.alexander38@yahoo.es

'Medical Center: José Manuel Seguí, Artemisa, Cuba

Full list of author information is available at the end of the article
}

reduction in asthma symptoms and medication use, as well as improvement in bronchial hyper-reactivity [2]. Even more, the U.S. Food and Drug Administration (FDA) approves the use of subcutaneous allergen extracts for the treatment of seasonal and perennial allergic rhinitis, allergic asthma, and venom sensitivity and recently approved the use of sublingual allergen extract for the treatment of certain grass pollen allergies [3].

Latin America (LA), the region of the Americas where Romance languages are primarily spoken, includes Mexico, most of Central and South America and in the Caribbean: Cuba, the Dominican Republic, and Puerto Rico. It is compounded by 20 countries and has an area of around 20 Million squared kilometers. Its population is estimated at almost 580 million people, where Brazil, Mexico, Colombia and Argentina are the most populated countries $[4,5]$.
Ciomed Central

(c) 2014 Diaz Rodriguez et al.; licensee BioMed Central Ltd. This is an Open Access article distributed under the terms of the Creative Commons Attribution License (http://creativecommons.org/licenses/by/4.0), which permits unrestricted use, distribution, and reproduction in any medium, provided the original work is properly credited. The Creative Commons Public Domain Dedication waiver (http://creativecommons.org/publicdomain/zero/1.0/) applies to the data made available in this article, unless otherwise stated. 
Cuba, officially the Republic of Cuba, is the main island country in the Caribbean. The island covers an area of approx. 110. 000 square kilometers and has a population of over 11 million people, and the climate is tropical and humid [6].

The purpose of this paper is to describe the present situation and future perspective of immunotherapy in Latin America and Cuba.

\section{Review}

\section{Latin America}

Dermatophagoides pteronissynus, Dermatophagoides farinae, Blomia tropicalis, Lepidoglyphus and Euroglyphus and are the most prevalent dust mites in LA [7-10]. Pollens are also very common in some areas, with a seasonal pattern in some countries like Argentina and Chile; other important allergens include cockroach and some airborne fungi like Alternaria and Aspergillus [11-16].

Sublingual and subcutaneous IT are practiced in all Latin-American countries, where allergic rhinitis and asthma are their most common indications [17-19]. IT for hymenoptera allergy is also common in the area, but there are few publications about it [20-22]. The majority of Latin-American countries use SCIT extracts from the United States and Europe and 50\% of them from local providers. On the other hand, SLIT extracts are mostly from Europe, but some countries like Argentina, Brazil, Cuba and Mexico prepare their own SL vaccines. Last, only a small number of countries fulfill regulatory status for their allergen products in the area; in this case Brazil, Cuba and in some extend, Argentina [17,23,24].

The number of studies on immunotherapy (IT) in Latin America has increased extensively in the last few years. The publications on adverse events with IT are beginning to appear. Only few countries have their own guidelines on IT, and, in general, the economic resources for medical research on IT are still low in the area [17].

A global approach for the future of IT in LA could be to improve standardization, quality control and the production of Latin American allergen products, to develop IT guidelines by the highest number of countries and to encourage clinical investigation on IT. Another important points comprises the improvement in regulatory status for allergens products in the area and the expansion in IT accessibility for low-income patients.

\section{Cuba}

There are 281 allergists in Cuba, with a ration of around 40.000 patients per allergist. Most of the Cuban allergists belong to the Cuban Society of Allergy, Asthma and Clinical Immunology, our national affiliation. Currently, we have 99 allergy services, mostly in primary care. There are 11 medicine faculties along the country supporting allergy residency, with 94 allergy professors [25].
It's been estimated that, at least, the $20 \%$ of the Cuban population suffer from allergy. Asthma prevalence is also high, ranging from 9 to $15 \%$ in general population. In children, according to the Cuban ISAAC (International Study of Asthma and Allergies in Childhood) Study, the prevalence for asthma, allergic rhinitis and atopic dermatitis in the ages 6-7 and 13-14 years, ranks high in the continent (Table 1) [26].

In Cuba, house dust mites are the most important allergen sources. Blomia tropicalis, Dermatophagoides pteronyssinus and Dermatophagoides siboney, which is a variant of Dermatophagoides farinae endemic in Cuba, are the most significant species [27-31] (Table 2). Some studies suggest that pollens, cockroaches and fungi could also be important, but more evidence is necessary to support it [32-37].

In the nineties, a biotech pole was created in Havana, and then in other provinces, including important scientific institutions and industries. All these centers work together on the application of Biotechnology into healthcare, developing and manufacturing vaccines and other biologic products. Cuban biotech pole involve more than 30 institutions, 15.000 workers, nearly 2.000 researchers and more than 150 research projects. There is a group of leading centers among them: the Center of Genetic Engineering and Biotechnology, the Center of Molecular Immunology and the National Center of Bioproducts (BioCen) [38]. The latter, also called BIOCEN is the place where the allergen-specific vaccines are produced at national scale.

To date, three standardized allergenic extracts (Blomia tropicalis, Dermatophagoides pteronyssinus and Dermatophagoides siboney) have been licensed in Cuba for their use as in-vivo diagnosis and specific immunotherapy for allergic diseases. These allergen vaccines were developed and registered in 2006: a standardized (in biologic units), freeze dried product for SCIT and the sublingual version was developed in 2009. In 2008, the vaccines were included into the group of basic medications by the Cuban Ministry of Health and the SL variant was incorporated in 2009. In 2011, as much as 23.000 IT treatments were provided to patients free of charge. About half the total IT vaccines were prescribed by sublingual route. The potency of Biocen vaccines were compared with Diater and ALK products with no statistically significant differences between them [39].

Table 1 Cuban ISAAC study 2002- 2004 [26]

\begin{tabular}{lll}
\hline Disease & $\mathbf{6 - 7}$ years & $\mathbf{1 3 - 1 4}$ years \\
\hline Asthma & $31.6 \%$ & $17.6 \%$ \\
Allergic rhinitis & $39.8 \%$ & $38.5 \%$ \\
Atopic dermatitis & $22.3 \%$ & $14 \%$ \\
\hline
\end{tabular}


Table 2 Most prevalent allergens in Cuba [27-31]

\begin{tabular}{|c|c|}
\hline \multicolumn{2}{|c|}{ Most prevalent allergens in Cuba } \\
\hline \multirow[t]{3}{*}{ Dust mites } & Dermatophagoides pteronyssinus \\
\hline & Dermatophagoides siboney (endemic) \\
\hline & Blomia tropicalis \\
\hline \multirow[t]{3}{*}{ Pollens } & Cynodon dactylon (Bermuda grass) \\
\hline & Parthenium hysterophorus (escoba amarga \\
\hline & Bidens pilosa (yellow grass) \\
\hline \multirow[t]{3}{*}{ Molds } & Penicillium notatum \\
\hline & Cladosporium herbarum \\
\hline & Alternaria tenuis \\
\hline Insects & Cockroaches (Periplaneta americana) \\
\hline
\end{tabular}

In 2012, a group of Cuban researchers developed an IT vaccine with adjuvant for subcutaneous route (Figure 1) [40-44]. This new vaccine uses Neisseria meningitidis proteoliposome, a bacterial product, as an adjuvant, added to the purified Dermatophagoides siboney major allergens: Der s1 and Der s2. From December 2012, this vaccine is in Phase I clinical trial to evaluate safety, tolerability and immunogenicity in asthmatic patients sensitized to this allergen. Another vaccine with the same adjuvant is also being developed with Blomia tropicalis.

There are 11 randomized, controlled clinical trials on IT (9 already finished), all registered at the Cuban public registry for clinical trials [45], available at URL: http:// rpcec.sld.cu/en/home. The first clinical trial applied in children is still in progress: a dose -response study by SL route. All these trials have used mite vaccines, and have had asthma as a target. There are also 3 studies on IT adverse events. Cuban allergists are currently working on their own guideline for allergen IT management. Also related, the Cuban Society of Allergology endorsed and co-organized, with the Cuban Immunology Society, two international meetings on allergen vaccines in 2009 and 2012 .

\begin{tabular}{|l|l|}
\hline 2012 & IT vaccine with adjuvant \\
2011 & 23.000 IT treatments \\
2009 & Sublingual variant \\
2008 & Included into the group of basic medicines \\
2006 & $\begin{array}{l}\text { First registered allergen vaccines (standardized } \\
\text { (BU), freeze dried for SCIT) }\end{array}$ \\
& $\begin{array}{l}\text { Figure } 1 \text { Chronology of development of immunotherapy } \\
\text { in Cuba. }\end{array}$ \\
\hline
\end{tabular}

Subcutaneous immunotherapy with Blomia tropicalis, Dermatophagoides pteronyssinus and Dermatophagoides siboney, the most prevalent Cuban dust mites, has proved to be effective and safe for the control and amelioration of asthma symptoms in asthmatic patients [40,42]. The therapeutic effect and safety of Dermatophagoides pteronyssinus, Dermatophagoides siboney and Blomia tropicalis was also demonstrated in asthmatic patients using SL route. Both clinical symptoms and medication intake were reduced compared to placebo. Allergen skin sensitivity also decreased significantly $(\mathrm{p}<$ 0.01). PEF (peak expiratory flow) variability also diminished significantly $(\mathrm{p}<0.05)$. The treatment was considered effective in $77 \%$ of patients. Local reactions were noted only in $0.43 \%$ of administrations and no systemic reactions were observed [41].

The Cuban perspectives on IT include to work on new indications for IT, to investigate the preventive effect and cost-effectiveness for current vaccines, to develop new products with mixed formulas of house dust mites for SLIT, to complete the phase I and II clinical study for dust mite plus adjuvant vaccine, to develop allergen vaccines for fungi allergy in asthmatics and to complete the Cuban guideline for allergen IT management.

\section{Conclusion}

Although most Latin American countries and Cuba are developing countries, much has been achieved in terms of treatment and research in immunotherapy, however, there are still some points requiring improvement in regard to immunotherapy in the area.

\section{Abbreviations}

LA: Latin America; SC: Subcutaneous; SL: Sublingual; IT: Immunotherapy; Der s1: Dermatophagoides siboney major allergen 1; Der s2: Dermatophagoides siboney major allergen 2; ISAAC: International study of asthma and allergies in childhood; BioCen: National center of bioproducts; PEF: Peak expiratory flow.

\section{Competing interests}

The authors declare that they have no competing interests.

\section{Authors' contributions}

ADR, ALR, RLCA and MAC equally contributed to writing the manuscript. All authors read and approved the final manuscript.

\section{Acknowledgements}

The authors thank the World Allergy Organization for the opportunity of submitting this article. Support for the dissemination of the WAO Immunotherapy and Biologics Online Monograph is provided by the following sponsors: Circassia, Boehringer-Ingleheim, and ORA Inc.

\section{Author details}

'Medical Center: José Manuel Seguí, Artemisa, Cuba. ${ }^{2}$ National Center of Bioproducts, BioCen, Mayabeque, Cuba. ${ }^{3}$ University Hospital "General Calixto García", Havana, Cuba.

Received: 18 April 2014 Accepted: 17 September 2014 Published: 12 November 2014 


\section{References}

1. Bousquet J, Lockey R, Malling H: WHO Position Paper. Allergen Immunotherapy: Therapeutic Vaccines for allergic diseases. Allergy 1998, 53(Suppl 44):1-42.

2. Abramson MJ, Puy RM, Weiner JM: Injection allergen immunotherapy for asthma. Cochrane Database Syst Rev 2010. CD001186. DOI: 10.1002/ 14651858.CD001 186.pub2. Available on URL: http://allergo.com.tr/eng/ allerjiliteratur_bankasi/astim_immun/Injection_allergen_immunotherapy_ for_asthma.pdf

3. US Food and Drug administration: Allergenics. in Vaccines, Blood \& Biologics; 2014. Available on URL: http://www.fda.gov/BiologicsBloodVaccines/ Allergenics/default.htm.

4. World Development Indicators: Latin America and the Caribbean. Annual report 2013, The World Bank. Available at URL: http://siteresources. worldbank.org/EXTANNREP2013/Resources/9304887-1377201212378/ 9305896-1377544753431/LACregion_EN.pdf.

5. Economic Commission for Latin America and the Caribbean (ECLAC): Statistical Yearbook for Latin America and the Caribbean, 2012 (LC/G.2554-P). Santiago, Chile, 2012. United Nations publication, Sales No. E/S.13.I..G. Available on URL: http://www.cepal.org/publicaciones/xml/2/48862/ anuarioestadistico2012.pdf.

6. Oficina Nacional de Estadística e Información. República de Cuba: Anuario Estadístico de Cuba 2012. Available on URL: http://www.one.cu/ EstadisticaPoblacion/EstadisticaPoblacion.asp.

7. Fernández-Caldas E, Lockey RF: Blomia tropicalis, a mite whose time has come. Allergy 2004, 59:1161-64. Available on URL: http://www.ctajournal. com/content/4/1/20.

8. Fernández-Caldas E, Baena-Cagnani CE, López M, Patiño C, Neffen HE, Sánchez-Medina M, Caraballo LR, Huerta-López J, Malka S, Naspitz CK: Cutaneous sensitivity to 6 mite species in asthmatic patients from 5 Latin American countries. J Investig Allergol Clin Immunol 1993, 3:245-249. Available on URL: http://www.ncbi.nlm.nih.gov/pubmed/8298748.

9. Calvo M, Fernández-Caldas E, Arellano P, Marín F, Carnés J, Hormaechea A: Mite allergen exposure, sensitisation and clinical symptoms in Valdivia, Chile. J Investig Allergol Clin Immunol 2005, 15(3):189-196. Available on URL: http://www.ncbi.nlm.nih.gov/pubmed/16261955?report=docsum.

10. Martínez-Jiménez NE, Aguilar-Angeles D, Rojas-Ramos E: Sensitization to Blomia tropicalis and Dermatophagoides pteronyssinus, farinae and siboney prevalence in patients with rhinitis, allergic asthma, or both, in a population of a metropolitan area of Mexico City. Rev Alerg Mex 2010, 57(1):3-10. Available on URL: http://www.ncbi.nlm.nih.gov/pubmed/20857623.

11. Sánchez-Borges M, Capriles-Hulett A, Malka S: Inhalant allergens clinically significant in Latin America. Allergy Clin Immunol Int J 2004, 16(1):28-32.

12. Sánchez-Borges M, Capriles-Hulett A, Caballero-Fonseca F, Fernández-Caldas E Mite and cockroach sensitization in allergic patients from Caracas, Venezuela. Ann Allergy Asthma Immunol 2003, 90(6):664-668. Available on URL: http://www. ncbinlm.nih.gov/pubmed/12839327.

13. Marinovic MA, Rojas R: Prevalence of Allergen Sensitization in Children with Atopy Suspicion between Six Months and Five Years of Age. World Allergy Organ J 2012, 5(Suppl 2):S198-S199. Available on URL: http://www. ncbi.nlm.nih.gov/pmc/articles/PMC3512799/.

14. Larenas-Linnemann D, Michels A, Dinger H, Shah-Hosseini K, Mösges $R$, Arias-Cruz A, Ambriz-Moreno M, Bedolla-Barajas M, Cerino-Javier R, del Prado ML C, Cruz-Moreno MA, García-Almaráz R, García-Cobas CY, GarciaImperial DA, Garcia-Muñoz R, Hernández-Colín D, Linares-Zapien FJ, LunaPech JA, Matta-Campos JJ, Martinez-Jiménez N, Medina-Ávalos MA, MedinaHernández A, Monteverde-Maldonado A, López DN, Pizano-Nazara LJ, Ramirez-Sanchez E, Ramos-López JD, Rodríguez-Pérez N, Rodríguez-Ortiz PG: Allergen sensitization linked to climate and age, not to intermittentpersistent rhinitis in a cross-sectional cohort study in the (sub)tropics. Clin Trans/ Allergy 2014, 4:20. Available on URL: http://www.ctajournal.com/ content/4/1/20.

15. Sanchez-Caraballo J, Diez-Zuluaga S, Cardona-Villa R: Sensibilización a aeroalergenos en pacientes alérgicos de Medellín, Colombia. Revista Alergia México 2012, 59(3):139-147. Available on URL: http://www.medigraphic. com/pdfs/revalemex/ram-2012/ram123f.pdf.

16. Baena-Cagnani CE, Fernández AM, Patiño CM, Salvucci KD: Reactividad cutánea a Periplaneta americana y Blatella germanica en pacientes asmáticos. Arch Arg Alergia Inmunol 1993, 24:180-185. Available on URL: http://bases.bireme.br/cgibin/wxislind.exe/iah/online/?lsisScript=iah/iah.xis\&src=google\&base=LILACS \&lang=p\&nextAction=Ink\&exprSearch=129853\&indexSearch=ID
17. Baena-Cagnani CE, Lockey RF, Passalacqua G, Canonica GW: Inmunoterapia en América Latina. Del pasado al futuro. Revista Alergia México 2008, 55(1):33-37.

18. García N, Lynch NR, Di Prisco MC, López Rl: Nonspecific changes in immunotherapy with house-dust extract. Curr Opin Allergy Clin Immunol 1995, 5:18-24

19. Walter Canonica G, Bousquet J, Casale T, Lockey RF, Baena-Cagnani CE, Pawankar R, Potter PC, Bousquet PJ, Cox LS, Durham SR, Nelson HS, Passalacqua G, Ryan DP, Brozek JL, Compalati E, Dahl R, Delgado L, Gerth Van Wijk R, Gower RG, Ledford DK, Filho NR, Valovirta EJ, Yusuf OM, Zuberbier T: Sub-Lingual Immunotherapy: World Allergy Organization. Position Paper 2009. World Allergy Organ J 2009, 21:233-281.

20. Guzmán MMA, Salinas LJ, Toche PP, Marinovic MMA, Gallardo OAM: Immunotherapy against hymenoptera venom: report of ten patients. Rev Med Chil 2007, 135(12):1566-1571. Available on URL: http://www.scielo. cl/scielo.php?script=sci_arttext\&pid=S0034-98872007001200010\&lng=en\& $\mathrm{nrm}=\mathrm{iso} \& \mathrm{ignore}=\mathrm{html}$.

21. BecerrilÁngeles $M:$ Inmunoterapia en pacientes alérgicos al veneno de abejas. Revista Alergia México 2010, 57(2):57-59. Available on URL: http:// www.medigraphic.com/pdfs/revalemex/ram-2010/ram102d.pdf.

22. Cuevas Hernández MM, Arías Hernández RM, Acuña Aguilarte P, Chichay Torres $L$ : Inmunoterapia con extracto de mosquito en niños con prúrigo por picaduras de este insecto. FOLIA DERMATOLÓGICA CUBANA 2009, 3(1). Available on URL: http://bvs.sld.cu/revistas/fdc/vol3_1_09/fdc05109.htm.

23. Baena-Cagnani CE, Larenas-Linnermann D, Gómez M, González-Díaz S, Solé D, Sánchez-Borges M, Bousquet J, Sisul JC, Walter-Canonica G, Gereda J, Passalacqua G: Allergy training and immunotherapy in Latin America: results of a regional overview. Ann Allergy Asthma Immunol 2013, 111 (5):415-419. Available on URL: http://www.sciencedirect.com/science/article/ pii/S1081120613005784.

24. Finegold I: Immunotherapy at the ACAAI Meeting. Immunotherapy 2008, 1(2):177-179. Available at URL: http://www.futuremedicine.com/doi/pdf/ 10.2217/IMT.09.1

25. Díaz-Rodríguez A: Allergology in Cuba. General overview and future perspectives. Junior Member News 2013. Available on URL: http://www. worldallergy.org/juniormembers/news/index.php?contentid=1387.

26. Solé D, Mallol J, Wandalsen GF, Aguirre V: Prevalence of Symptoms of Eczema in Latin America: Results of the International Study of Asthma and Allergies in Childhood (ISAAC) Phase 3. I Investig Allergol Clin Immunol 2010; 20(4):311-323. Available on URL: http://www.jiaci.org/issues/ vol20issue4/6.pdf.

27. Castro RL, González M, Labrada A, Navarro B, Álvarez-Castelló M, GarcíaGómez I: Sensibilización a Dermatophagoides pteronyssinus, Dermatophagoides siboney y Blomia tropicalis en niños de tres consultorios. Rev Cubana Med Gen Integr 2005, 21(3-4). Available at URL: http://scielo.sld.cu/scielo.php?script=sci_arttext\&pid=\$0864-21252005000 300022\&lng=en\&nrm=i\&tlng=es.

28. Castro ARL, Álvarez CM, Ronquillo DM, Rodríguez JS, García-Gómez I, GonzálezLeón M, Enríquez-Domínguez I, Labrada A, Navarro B, Oliva-Díaz Y, MateoMorejón M: Sensibilización a tres especies de ácaros en pacientes alérgicos de la zona costera de la ciudad de La Habana. Rev Alerg Mex 2009, 56(2):31-35.

29. Díaz-Rodríquez A, Fabré-Ortiz DE, Coutin MG, Gonzáles-Méndez T: Sensitization to Mites. Relation with Atopic Diseases in School Children from San Antonio de los Baños. Rev Alergia México 2009, 56(3):80-85 Available at URL: http://www.ncbi.nlm.nih.gov/pubmed/19623784.

30. Pérez-Pacaréu ML, García-Díaz A, Sabina-Díaz A, Vega-Galindo M: Sensibilización a diferentes tipos de ácaros en pacientes adultos. Rev cubana med 2002, 41(n.2):74-80. ISSN 1561-302X. Available on URL: http//wwww.oalib.com/paper/ 2265876\#.U-_ImXPD_48.

31. Reyes-Zamora MC, Labrada-Rosado A, Mateo-Morejón M, López-Chacón A: Sensibilización a tres ácaros domésticos en una población infantil alérgica de Cuba. Revista Alergia México 2012, 59(3):148-154. Available on URL: http:// www.medigraphic.com/pdfs/revalemex/ram-2012/ram123g.pdf.

32. Rodríguez O, Célio R, Aboukhair F, Laurrabaquio AM, Tinoco IO, Cuevas HU, Cruz SMÁ, Cruz MMÁ, Reyes MC: Skin test with allergen extracts from pollens and relation to clinical signs of allergic rhinitis and bronchial asthma in Camagüey, Cuba. VacciMonitor 2013, 22(2):9-13. ISSN 1025-028X. Available on URL: http://scielo.sld.cu/scielo.php?pid=S1025-028X2013000200002\&script=sci abstract\&tlng=en

33. Rodríguez Pérez J, Sarduy Ramos CM, Pérez Fabelo M, Gutiérrez Candelario Z: Clinical diagnostic assay with allergenic extract of Cynodon dactylon pollen in patients with asthma and/or rhinitis. Arch. Méd. Camaguey 2009, 13(4). Available 
on URL: http://scielo.sld.cu/scielo.php?script=sci_abstract\&pid=\$1025-025520090 00400003\&lng=es\&nrm=iso\&tlng=en.

34. Rodríguez Santos O, Rodríguez Gavaldá R, Silva Pérez R: Ensayo clínico diagnóstico en pacientes alérgicos con extracto de polen de Parthenium hysterophorus. Rev Alergia Mex Mar-Abr 2001, 48(2):45-47. Available on URL:http://www.imbiomed.com.mx/1/1/articulos.php?method=showD etail\&id_articulo=3361\&id_seccion=64\&id_ejemplar=385\&id_revista $=12$

35. Rodríguez-Puentes M, Sánchez-Rodríguez A, Castro-Almarales RL, AbdoRodríguez A, Aranda-Rivero RE, Labrada-Rosado A: Sensibilización a Periplaneta americana en pacientes con asma. Alergia, Asma e Inmunología Pediátricas 1999, 8(2):37-39. Available on URL: http://www.medigraphic. com/pdfs/alergia/al-1999/al992b.pdf.

36. Diaz-Rodriguez A: Fungal sensitization and its relation to asthma and allergic rhinitis in children aged 6 to 7 years. World Allergy Organ J 2012, 5(Suppl 2): S86. Available at: http://www.ncbi.nlm.nih.gov/pmc/articles/ PMC3513128/.

37. Almaguer M, Rojas-Flores Tl: Airborne culturable fungi of the atmosphere of Havana, Cuba. Nova Acta Científica Compostelana (Bioloxía) 2013, 20:35-45. ISSN 1130-9717. Available on URL: http://www.usc.es/revistas/index.php/nacc/ article/view/1404.

38. Rodríguez León N: Cuban Biotechnology: An Industry of Excellence. Excelencias magazines 2010, (10). Available on URL: http://www. revistasexcelencias.com/en/excelencias-turisticas-cuba/latin-america-newrealities/industria/cuban-biotechnology-industry-excel.

39. Rodríguez O, Labrada-Rosado A, Célio R, Aboukhair F, Roberto-Meli V, JuliánBarata H, Cruz-Suárez MA, Cruz-Marmolejo MA: Comparación de la potencia de extractos alergénicos de ácaros en pacientes con asma y rinitis alérgica. VacciMonitor 2012, 21(1):25-29. Available on URL: http:// www.finlay.sld.cu/publicaciones/vaccimonitorN/2012/a6.pdf.

40. Ronquillo-Díaz MM, Castro-Almarales RL, Alvarez-Castelló M, Labrada-Rosado A, et al: Primeros ensayos clínicos a doble ciega controlados con placebo con las vacunas antialérgicas VALERGEN-DP, VALERGEN-DS Y VALERGEN-BT en asmáticos en Cuba. Trabajos Premiados en el XXXIII Concurso Nacional "Premio Anual de la Salud 2008". Boletín CNSCS 2009, 1:1-25. ISSN 2073-9281.

41. Almarales, et al: Immunotherapy - 2072. Therapeutic effect and higher safety profile for allergic asthma in Cuban patients with sublingual immunotherapy using tropical domestic mite allergen vaccines. World Allergy Organ J 2013, 6(1):P154.

42. Almarales, et al: Immunotherapy - 2073. Therapeutic effect of mite allergen vaccines by subcutaneous route in allergic Cuban asthmatic patients. World Allergy Organ J 2013, 6(Suppl 1):P155

43. Almarales, et al: Immunotherapy - 2074. Tolerability of sublingual immunotherapy with tropical mite allergen vaccines using different dosing schedules in asthmatic children. World Allergy Organ J 2013, 6(Suppl 1):P156.

44. Labrada A, Facenda E, Castro RL, Fernández Bl, Uyema K, Sewer M, Aranda RE, Más A, Navarro B, Jorge O, Novoa I, Díaz J, Bourg V: State of the art in developing allergen vaccines in Cuba: prospects of novel adjuvanted vaccines. Vaccine 2006, 24(Suppl 2):S2/36-S2/37.

45. Jiménez G, Pascual MA, Fors $M$, Cobas J, Torres A, Cachimaille $Y$, Rodríguez J, López I: The Cuban Public Registry of Clinical Trials: primary registry of World Health Organization. J Evid Based Med 2011, 4(3):161-164. Available on URL: http://www.ncbi.nlm.nih.gov/pubmed/21894615.

doi:10.1186/1939-4551-7-28

Cite this article as: Diaz Rodriguez et al:: Current status and future perspectives of immunotherapy in Latin America and Cuba. World Allergy Organization Journal 2014 7:28

\section{Submit your next manuscript to BioMed Central and take full advantage of:}

- Convenient online submission

- Thorough peer review

- No space constraints or color figure charges

- Immediate publication on acceptance

- Inclusion in PubMed, CAS, Scopus and Google Scholar

- Research which is freely available for redistribution

Submit your manuscript at www.biomedcentral.com/submit 